\title{
Lucta contra os Escorpiões
}

\author{
pelos
}

Drs. Ezequiel Dias, Samuel Libanio e Marques Lisbó.

(Trabalho do Instituto Oswaldo Cruz (Filial) de Bello Horizonte. E. de Minas).

(Com a estampa 1.)

Em conformidade com a ecologia dos escorpionideos existentes no Brazil central, com especialidade no Estado de Minas Geraes, dois deveriam ser os pontos indicados para o combate a esses arachnideos:

\section{0-nos campos;}

20-nas habitações humanas.

Dada a vasta distribuição geographica dos referidos arthropodes, não nos parece pratica nem opportuna a primeira parte do problema. Mas, si a civilização tivesse attingido a tal grau e a riqueza publica a taes proporções que comportassem semelhante campanha de exterminio, seria por ahi que haviamos de começar, porque é do seu habitat natural, isto é, da natureza livre, que o cscorpião veiu e ainda vem para o interior dos nossos domicilios.

No Mexico, onde o Centrurus gracilis determina terriveis acccidentes, já se fez uma tentativa dessa ordem, pois as auctoridades chegaram a estabelecer pre- mios para os exlerminadores desses inimigos. Só n'um verão diz O. FASCHENBERG que foram déstruidos de 80.000 a 100.000 .

O Instituto OSWALDO CRUZ de Bello Horizonte, embora sem intuitos prophylacticos, tambem costuma ter ensejo de verificar a exequibilidade d'essa extranha caçada, quando tem em mira a preparação do sôro anti-escorpionico. E por coincidencia, n'um periodo de 6 annos, adquiriu 107.533 exemplares vivos e morios, pelo preço de 9:941 $\$ 950$.

E' claro, porêm, que, por emquanto, não pensamos em uma campanha systemalica por esse meio. Entretanto, não padece duvida que nos lugares onde tem sido realizada a referida compra, baixou sensivelmente o numero de escorpiões.

No momento actual, o que se nos afigura pratico é a $2^{\text {a }}$. parte do pro- 
blema, isto é, uma guerra de morte aos escorpionideos que se acoitam na vivenda humana e suas immediações.

Com esse objectivo estudamos 3 ordens de medidas:

a)-meios escorpionicidas;

b) -construcção de predios inadaptaveis á vida e procreação dos escorpiões;

c)-medidas complementares.

\section{I}

\section{MEIOS ESCORPIONICIDAS.}

\section{ENSAIOS PRELIMINARES.}

Afim de sondar a resistencia dos nossos arthropodes, começamos por esbocar diversos ensaios de laboratoriq effectuando algumas experiencias in vitro.

Trabalhámos com o escorpião mais frequente em Bello Horizonte-Tityus serrulatus e uma ou outra vez com o $T$. bahiensis e o T. dorsomaculatus. No inicio do trabalho suppunhamos, como era corrente entre os especialistas, que aqui havia apenas o $T$. bahiensis: mas $\mathrm{A}$. LUTZ e O. MELLO crearam com muito acerto aquellas duas especies novas, que hoje não se confundem o $T$. bahiensis.

Alem disso, para aproveitar mais amplamente o nosso esforco e tornal-o talvez mais instructivo, submettemos tambem aos nossos ensaios alguns insectos parasitas e outros animaes nocivos ou incommodos.

Acção do xylol.-Era natural que nos lembrassemos em pritneiro logar d'esse insecticida tão empregado pelos entomologistas e colleccionadores. riencias:

Eis o protocollo de uma $d$ as expe-

Ás 16 horas foi collocado 1 escorpião n’um vidro de bocca larga em cuja rolha de algodão se deitaram 4 goltas de xylol. Primeiramente, 0 animalzinho permaneceu immovel, Passados 3 minutos, entrou a se agitar para em scguida cahir, sempre em contracções, no fundo do frasco, onde se quedou semi-morto. A ultima parte a perder os movimentos foi a extremidade caudal, séde do veneno. Meia hora depois ainda jazia inerte no mesmo logar, de ventre para cima, de modo que a cauda formava um arco com o corpo. D'essa hora em deante parece que não manifestou o minimo signal de vida. No dia seguinte confirmou-se a morte.

O mesmo agente chimico, em igualdade de condições, mata percevejos, pulgas, baratas, aranhas, moscas, mosquitos, lepismas; o proprio «barbeiro» (Triatoma megista) apezar da sua enorme vilalidade, não lhe resiste á acção toxica,

Chloroformio (*).--Collocou-se o escorpião n'um vidro grande, dentro do qual é introduzido tambem 1 tubo de BORREL com 2 c. c. de chloroformio. Não ha periodo de excitação, $O$ animal anda pelo fundo do vaso. Os movimentos vão se tornando mais lentos; alguns minutos depois, fica paralysado, como morto, e a cauda, que se mantinha erecta, cahe para um lado; mas o escorpião ainda reage ás excitações externas. Pouco depois, pequena excilação; alça a cauda, mantem-se immovel, com as patas e os palpos maxillares afastados e a cauda curvada sobre o tronco. Ás vezes, esta é animada de tremores. Meia hora depois do inicio da experiencia, a excitação externa ainda provoca pequenos movimentos do ultimo segmento caudal. 45 minutos depois não apresenta mais signal de vida, pelo que é retirado do recipiente. A cauda ainda reage á excitação. Morte.

Acido cyanhydrico - N'uma campanula de vidro sobreposta a uma placa de madeira, com um sulco circular cheio de agua para tornar perfeitos o en-

$\left({ }^{*}\right)$-Experiencia devida á gentileza do Dr. Oswaldo Mello, 
caixe e a vedação, foi collocado um calice com 3 c. c. de agua e 1 de acido sulfurico. Um saquinho com 1 gr. de cyanureto de potassio pendia da rolha da campanula, de tal modo que elle mergulhava no calice justamente quando a rolha obturava o respectivo orificio. Com esse dispositivo se conseguia formar rapidamente o acido cyanhydrico, sem qualquer perigo para o operador, nem perda da minima porção de gaz.

Nesse ambiente succumbiram após 10 minutos: 1 escorpião, 1 dezena de percevejos, 1 nympha de "barbeiro» (Triatoma), e 1 rato branco. 0 menos resistente foi o rato, e o mais resistente o escorpião.

Gazolina-Na dose de 3 gottas e nas mesmas condições do xylol, a gazolina é incapaz de matar o escorpião, não obstante as torturas por que este passa. No emtanto, mata a formiga, o percevejo, etc. E' de crer que, augmentada a dose, consiga melhor resultado.

Naphtalina-Debaixo de uma campanula de vidro collocada sobre uma mesa, sem calafetagem, foram postos: ao centro 5 grammas de naphtalina em uma capsula de porcellana, que era aquecida por uma lampada de alcool; aos lados, diversos animaes de experiencia, cada um no seu frasco arrolhado de algodão,

Desprenderam-se immediatamente abundantes vapores quasi negros, e ao cabo de 1 hora viam-se bellos crystaes brancos depositados por toda a parte. Submetteram-se a esse ambiente: 1 escorpião, 1 camondongo, 2 percevejos e 1 "barbeiro»: Mostram-se logo agitados, principalmente o ratinho. Este, após 3 horas, apresentava-se triste, prostado, dyspneico. O escorpião, denotando horriveis soffrimentos, tinha contorsões violentas, rodopiando em todos os sentidos, ás vezes de ventre para cima, com uma gotticula de veneno a brilhar na ponta do ferrão. O triatoma e os percevejos, tambem em decubito dorsal, moviam, de quando em quando, alguns dos membros.

Resultado: camondongo-morto 5 horas depois; percevejos um morreu após 5 horas; outro depois de 15 horas; escorpião morto em 13 horas; barbeiro-morto em 15 horas.

Gaezs de carvão de pedra-Aquecido em uma retorta o carvão mineral virgem, eram os gazes conduzidos para um vidro onde se achavam 1 escorpião ie 1 "barbeiro". Em 1/4 de hora estavam em agonia e morriam pouco depois. Formou-se, entretanto, alguma humidade, que talvez concorresse para a rapidez do resultado. Repetida, porêm, a experiencia, sem essa causa de erro, os mesmos gazes mataram no mesmo espaço de tempo, 2 larvas de barbeiro e 3 percevejos (nesse dia não tivemos outro escorpião).

Sulfureto de carbono - 5 c. c. N'um calice debaixo de uma campanha bem vedada. $1,15 \mathrm{~h}$. depois morreram 1 escorpião e 4 baratas. Nas mesmas condições, 1 hora depois morreu 1 escorpião.

Ainda nas mesmas condições, no fim de 25 minutos só 1 aranha succumbiu; 1 escorpião, 2 baratas e 2 outras aranhas resistiram.

Gaz sulfuroso.-(*) As 12,43 horas é collocado um escorpião n'um vidro grande, cheio desse gaz. Excitação immediata. Depois elle passeia pelo fundo do vaso. Ás 13 horas, excitação forte, mas pouco duradoura; em sezuida cahe como morto no fundo do recipiente. Retirado d'ahi, dá ainda signal de vida: movimentos caudaes. Esses, porêm, cessam completamente, quer os espontaneos, quer os provocados. Morte.

Desses ligeiros ensaios preliminares deviamos concluir que ha meios seguros

(") Experiencia realizada pelo Dr. Oswaldo Mello. 
e rapiđos para matar o escorpião; e d'entre esses meios talvez pudessemos contar com o acido cyanhydrico, o gaz de carvão mineral., o gaz sulfuroso, o sulfureto de carbono, o xylol, o chloroformio e a naphtalina.

A proposito das doses de gazes toxicos, não nos foi dado verificar a observação de EMILE BLANCHARD, que, confirmando a de WILLIAM EDWARDS sobre os insectos, notou que o excesso desses gazes é contraproducente, poiz o escorpião cessa de respirar em taes condições, por lh'o permitlir o seu apparelho respiratorio $\mathrm{e}$ as suas funcções muito sobrias; ao passo que, sendo o ar apenas viciado, a morte sobrevem rapidamen!e, porque o animal não suspende a respiração e vai insensivelmente se intoxicando.

Seria desejavel que a razão estivesse com esses auctores, porque n'esse caso devia ser muito mais facil a destruição de taes inimigos.

\section{EXPERIENCIAS EM PEQUENOS COM- PARTIMENTOS.}

Parecendo-nos conveniente modificar o determinismo experimental até aqui adoptado, passámos a realizar os ensaios em espaços menos restrictos, approximando-nos gradativamente das condições naturaes.

Utilizámo-nos para isso do nosso quarto photographico ( $7,300 \mathrm{~m} 3$ ) onde eram collocados os animaes, sempre longe da entrada dos gazes toxicos, que por sua vez cram produzidos fóra da camara e para esta canalizados cuidadosamente. Além disso, procediamos á calafetagem rigorosa com papel e gomma, de modo a não haver nenhum escapamento. Cercavamo-nos tambem de grandes cautelas, porque muitas vezes trabalhavamos com gazes inflammaveis, além de toxicos.

Eis alguns ensaios:

Gaz acetyleno.-Duração da experiencir: 21 looras. Resullado negativo para escorplöes, batberos adultos e larvas. percevejos e barata. Posilivo para os ratos, unicos animaes que succumbiram, Chloro.-Depois de 24 horas peimaneciam vivos o escorpião, as larvas de barbeiro, a barata e o rato.

Formol.-Empregado o apparelho de HOTON, corfirmou-se ainda uma vez a má acção parasiticida do formol, que cm 24 horas não matou o escorpião.

Gaz de carvão mineral.--Os gazes produzidos pelo aquecimento de $1 / 2 \mathrm{gr}$. de carvão bruto foram inoffensivos para escorpiões, larvas de barbeiro, rato e barata (24 horas).

Receiando algum accidente no gabinele photographico, que é de madeira, resolvemos trabalhar n'um dos porões do Instituto ( $52 \mathrm{~m} .3$ ).

Assim expcrimentámos:

Creolina.-Em panellas de ferro collocadas no interior do compartimento foi aquecido esse liquido na proporção de 10 c. c. para cada metro cubico de espaco. Resultado negativo, em 24 horas, para escorpião, percevejos, barata, camondongo e rato.

Naphtalina.-Nas mesmas condicões anteriores foram aquecidas 14 grammas, por metro cubico, tambem com resultado negativo.

Pixe.-Idem, idem, na proporção de 12 grs. por metro cubico, com identico resultado. Para esse ensaio tivemos escorpião vivo, mas pela resistencia dos outros animaes pudemos avaliar a inefficacia do processo.

Carvão de pedra nacional.-4 kilos aquecidos duranle 3 horas. Os gazes, que se iam produzindo, eram canalizados para o interior do porão, que ficou fechado por espaco de 24 horas.

Inoffensivo para escorpiões, baratas, ratos, larvas de triatoma.

Gaz acetyleno. -6 kilos de carbureto de calcio em 24 horas. Nas mesmas con- 
dições da experiencia anterior, foi inefficaz para os mencionados animaes.

Chloro.--Em 24 horas não ma'ou escorpião, barbeiro, barata c rato.

\section{GAZ SULFUROSO.}

Em vista dos resultados negativos em espacos relativamente amplos, tivemos de abandonar muitos dos toxicos anteriormente refe idos, bem como receiamos lançar mão do melhor d'elles-o acido cyanhydrico-por offerecer serios perigos. Não obstante, os norte-americanos empregam este ultimo em larga escala, como meio de defeza agricola, no expurgo de arvores parasitadas, especialmente nos laranjaes da California, usando para isso de uma technica muito orignal, talvez applicavel ás nossas «cafuas (choupanas) infestadas de «barbeiros". Lá, porêm, elles trabalham ao ar livre, servindo-se de barracas portateis, que envolvem toda a arvore; aqui teriamos de agir no interior das casas, com a renovação mas difficil do ar, sem as turmas adextradas que elles possuem.

Por esse e outros motivos desistimos de tentar o poderoso toxico, reservande nossos estorços para o gaz sulfuroso, que aliás já é empregado com exito completo na prophylaxia da febre amarella e com algum resultado na destriução dos ratos. Além disso, te:n a vantagem de ser barato, de manejo conhecido e inoffensivo para o homem, bom parasiticida, ligeiramente antiseptico, ind:cado na extincção de incendios. LLOYD MILLS, no Mexico, recommenda-o contra o proprio escorpião, mas não estabelece a lechnica, nem diz as condicões em que deve ser eficiente, si é que, de facto, o experimentou.

Entre'anto, algumas experiencias preparatorias aqui realizadas em espaços relativamente amplos, mas sem o necessario rigor, chezaram a dar-nos a impressão de que o maligno arachnideo era capaz de resistir frequentes vezes, ao anhydrido sulfuroso. No emtanto, desde que o empregámos com energia, con- vencemo-nos da sua ellicacia, pelo menos expcrimentalmente.

Naluralmente, foi com certo exaggero que se fizeram alguns desses ensaios, empregando doses aliás, ás veze.; superfluas, pois é sabido que a combustão do enxof:c tem um limite, mais ou menos calculado em 65 grammas por metro cubico de espaco confinado.

Dos tres processos mais conhecidos, apenas deixamos de usar o do gaz sulfuroso liquido, que, lalvez por causa do preço, não é encontrado actualmcinte nos nossos mercados. Entreianto, a não ser o inconveniente do custo elevado, deve elle ser altamente commodo, pratico e efficaz, além de simples e elegante.

Na falta desse recu:so, servimo-nos do apparelho CLAYTON e do processo mais corrente e barato, que é o da simples combustão do enxofie em recipientes de ferro collocados no interior dos aposentos a fumigar, sendo estes rigorosamezte calafetados pelos meios communs na pratica sanitaria.

\section{EXPERIENGIA No. 1 (*).}

Camara de $7,350 \mathrm{~m}^{3}$. (do De infectorio). Enxofre: 142 grs. por $\mathrm{m}^{3}$. Animaes collocados na parte mais alta: 2 escorpiões, 2 larvas de barbeiro, 2 baratas e 1 rato. Quando se abriu a camara no fim de 24 horas, estavam todos moltos.

\section{EXPERIENCIA No. 2.}

Camara para desinfecção de carros (Desinfectorio) com 48,731 $\mathrm{m}^{3}$. Cerca de 100 grs. de enxofre por $\mathrm{m}^{3}$; $6 \%$ de nitro e $20 \%$ de alcool. Animaes collocados no alto: (**) 2 escorpiões, 2 bar-

$\left({ }^{*} ;\right.$ - Toda esta serie de experiencias foi feita peia simples combustão de enxofre. O Clayton só posteriormente foi utilizado.

(") - Em quasi todas as experiencias os animaes foram collocados em vidros largos com rolha de algodão. Só os rates é que costumavam ficar em caixas perfuradas ou com tela de arame. 
beiros, 2 baralas e 2 ratos. Ao cabo de 24 horas, todos mortos.

\section{EXPERIENCIA No. 3.}

Porão do Instituto de Bello Horizonte $\left(52 \mathrm{~m}^{3}\right) .38 \mathrm{grs}$. de enxofre por $\mathrm{m}^{3}$. ( $1 \%$ de nitro). Collocados á meia altura: 2 escorpiões, 2 baratas, 2 barbeiros c 2 ratos. Todos mortos, após 24 horas. O material empregado era flor de enxofre, que só ardeu na proporção de 10 grs. por $\mathrm{m}^{3}$.

\section{EXPERIENCIA No. 4.}

Mesmo porão. 34 grs. de enxofre por $\mathrm{m}^{3} . \quad 1 \%$ de nitro e $10 \%$ de alcool do commercio. Collocados no chão: 2 escorpiões, 2 larvas de barbeiro, 2 barbeiros adultos, 2 baratas $\mathrm{e}$ 2 ratos. Apezar do tempo humido, todos os bichos succumbiram em 24 horas.

ror essas experiencias poderiamos suppor que nada mais facil do que exterminar escorpiões, triatomas, ratos, etc. Cumpre-nos declarar que nem sempre foi esse o resultado obtido; e assim aconteceu ora por falta de pessoal habilitado ao serviço, que exige technica e tirocinio, ora pela qualidade de material. O enxofre, sobretudo, é frequentemente conspurcado por impurezas que difficultam a combustão, taes como sulfato de sodio, areia, etc.. Convém, portanto, escolhel-o de boa qualidade, em bastões, e reduzil-o a pó no momento de servir. E' indispensavel tambem addicionar-lhe um pouco de nitro ou de alcool, afim de favorecer a combustão. Finalmente, nunca empregar ingredientes humidos.

Para darmos uma idéa da inconstancia dos primeiros resultados, devemos dizer que além das 4 experiencias felizes, acima relatadas, tambem tivemos 3 negativas e 4 incompletas, de modo que sobre um tolal de 11 sómente $36 \%$ foram perfeitamente positivas.

Convencidos de que a humidade foi o factor primordial de taes fracassos, e como estavamos em plena estação chuvosa, planejámos combater esse inconveniente por meio de um preparado secco e de rapida combustão, adoptando para isso a seguinte formula.

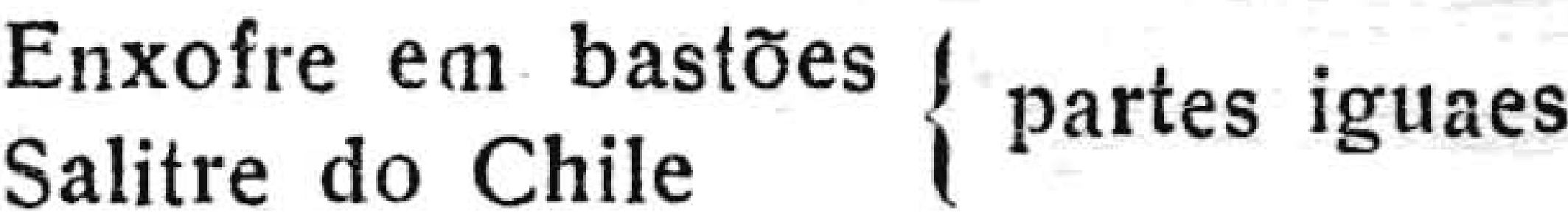

Triturámos muito bem as duas substancias; misturámol-as; addicionámos á mistura um pouco de agua, formando assim uma pasta mais ou menos molle, que distribuimos em fôrmas conicas de papel (cartuchos) que foram postas a secccar n'uma estufa, em calor brando (na falta de estufa, pode servir qual'quer forno de uso domestico). Depois de totalmente seccos, esses blocos foram retirados da estufa, libertados do papel envolvente, ficando assim promptos para o serviço.

E assim obtivemos um producto commodo, barato e simples. Em qualquer logarejo, um leigo pode preparal-o e usal-o. Na estação secca elle se conserva $\mathrm{cm}$ boas condições, durante muito tempo. Por occasião das chuvas, porêm, humedece-se com facilidade, si não fôr cuidadosamente resguardado. Mas contra isso ha um recurso: a cera aquecida, que, cnvolvendo-o completamente, lhe constitue um revestimento protector que deve ser raspado no momento de accender o gaz.

Encontrava-se outr'ora no mercado um producto extrangeiro, em latas pequenas, que continham uma mistura sulfurea, solida, provida de um pavio. Si não fosse o preço, naturalmente elevado e a sua falta absoluta nas casas importadoras, não hesitariamos em recommendal-o, porque satifaz a todos os requisitos e indicações.

$\mathrm{Na}$ falta de melhores recursos, acon- 
selhamos o emprego dos cones sulfureos, que deram experimentalmenté os seguintes resultados:

\section{EXPERIENCIA A1.}

Porão do Instituto $\left( \pm 52 \mathrm{~m}^{3}\right)$. Empregaram-se 8 cones com o peso total de 1.267 grs., isto é, 24 grs. da mistura nitro-sulfurea para cada metro cubico de espaço a expurgar, ou \pm 12 grs. de enxotre por $\mathrm{m}^{3}$. Animaes experimentados: 2 escorpiões, 2 larvas de barbeiro, 2 baratas e 2 ratos (metade collocada no chão, metade em cma da mesa). Em 24 horas todos mortos.

\section{EXPERIENCIA A 2.}

No mesmo porão, 6 cones com o peso total de 1.200 grs. ( \pm 11 grs. de enxofre por $\mathrm{m}^{3}$.). Animaes: 1 escorpião, 2 larvas de barbeiro, 1 barata e 1 rato. Além disso, para comprovar a applicacão do gaz sulfuroso contra os incendios, fizemos arder no mesmo compartimento uma fogueira de lenha. Ao cabo de 24 horas, esta só tinha queimado pela metade. Us bichos estavam mortos.

\section{EXPERIENCIA A 3}

No mesmo local arterior, ficando os animaes n'uma extremidade, dentre de um armario com tela de arame, ao passo que os cones arderam na extremidade opposta, a $7 \mathrm{~m}$. 67 de distancia. 1 escorpião, 1 larva de barbeiro, 1 barata e 1 rato, collocados no chão, morreram após 24 horas. Gastaram-se $\mathbf{1 . 3 5 0}$ grs. do producto nitro-sulfureo $( \pm 13$ grs. de enxofre por $\mathrm{m}^{3}$.). Convém notarmos que um ratinho, desapparecido anteriormente, appareceu tambem morto.

\section{EXPERIENCIA A 4.}

No mesmo compartimento, diminuido apenas o numero de horas, que em vez de 24 passou a ser 12 . Além dos bichos, que eram 2 escorpioes, 1 larva de barbeiro, 1 barata, 1 lepisma e 1 rato adulto, foram expostas culturas de bacillos dysentericos FLEXNER e HISSRUSSEL, cholerico, typhico, diphtherico, pyocyanico, enterotidis e mallei. Arderam sómente 3 cones ( \pm 6 grs. de enxofre por $\mathrm{m}^{3}$.). Apezar desse contratempo, talvez devido á grande humidade do dia, succcumbiram todos os animaes $\mathrm{cm}$ 12 horas. E si bem que o determinismo experimental não fosse perfeito, confirmou-se ainda uma vez o fraco poder bactericida do gaz sulfuroso, que foi incapaz de esterilizar as culturas referidas, embora estas fossem de bacterias não esporuladas.

\section{EXPERIENCIA A 5.}

Idem, idem, nas condições da experiencia anterior. 3 cones com 494 grs. de peso total $( \pm 4,50$ grs. de enxofre por $\mathrm{m}^{3}$.). 7 horas depois morriam, 1 larva de barbeiro, 1 barata e 1 rato. (o escorpião agonizante veiu a morrer pouco depois).

D'aqui por diante procurámos tornar mais rigoroso o determinismo experimental, collocando os animaes em lugares de difficil accesso ao agente toxico, como acontece, de regra, em condições naturaes. Assim, apezar de incompletos alguns dos resultados, nem por isso deixam elles de ser significativos.

\section{EXPERIENCIA A 6.}

Porão do Instituto. 3 cones encerados, com o peso total de $1 / 2 \mathrm{kgr}$. ( \pm 5 grs. por $\mathrm{m}^{3}$.). Todos os pequenos animaes foram postos em vidros arrolhados com algodão, como habitualmente; além disso, alguns foram ainda envolvidos em pannos, e outros mettidos dentro da palha de um colchão, ficando tudo isso a 7 metros de distancia do combustor de enxofre.

No fim de 24 horas appareceram morlos: 
a) todos os bichos que estavam simplesmente em vidros arrolhados com algodão, isto é, 1 escorpião, 2 pulgas, 1 larva de barbeiro, 1 barata e 2 percevejos;

b)-todos os que se achavam envolvidos em pannos: 1 escorpião, 2 pulgas, 1 larva de barbeiro, 1 barata e 2 perceve.jos;

c)-dentro do colchão; 3 pulgas $\mathrm{e}$ 4 percevejos.

Sobreviveram :- apenas um rato (n'um caixote com orificios) e 1 pulga, dentro do colchão.

\section{EXPERIENCIA A 7.}

No mesmo local; 7 cones encerados com o peso total de 1 kilo ( $\pm 91 / 2$ grs. de enxofre por $\mathrm{m}^{3}$.). Tempo: 12 horas.

Mortos:

a)-em vidros com algodão: 1 escorpião, 1 barata, 2 pulgas, 2 percevejos e 1 larva de barbeiro;

b) - envoltos em panno: 1 escorpião, 1 barata, 2 pulgas, 2 percevejos e 1 larva de barbeiro;

c)-dentro do colchão: 1 escorpião, 1 barata, 4 pulgas, 4 percevejos e 1 larva de barbeiro.

d)-n'uma caixa com orificios: 1 dos ratos.

Sobrevivente :- apcnas outro rato, mas esse mesmo veiu a morrer no dia seguinte.

\section{EXPERIENCIA A 8}

No mesmo porão; 5 cones encerados, com 1 kilo de peso ( $\pm 91 / 2$ grs. de enxofre por $\mathrm{m}^{3}$.). Tempo: 6 horas.

Mortos:

a) $-\mathrm{cm}$ vidros com algodão: 1 barata, 2 pulgas e 2 percevejos;

b) -cuvolta em panno: 1 barata;

c)-dentro do colchão: 1 barata, 2 pulgas e 2 percevejos.

Vivos:

2 ratos, sendo $1 \mathrm{~cm}$ caixa com orificios e outro em caixa semi-aberta.
Além disso, foram cxpostas á acção do gaz: 3 culturas en caldo (recentemente deseccadas) de bacillos dysentericos FLEXNER e SHIGA e de $b$. mal'ei. Esta resistiu, as outras morreram.

\section{EXPERIENCIA A 9.}

No mesmo local. Duração da experiencia: 3 horas. Mas convém notar que deixaram de arder 580 grs. da mistura nitro-sulfurea.

Morreram : vejos;

a) -nos vidros com al godão: 2 perce-

b)-cnvolvidos cm panno: 1 barata, e 2 percevejos;

Resistiram:

a) - em vidro com algodão; 1 barata.

b)-dentro do colchão: 1 barata $\mathrm{e}$ 2 percevejos.

Tambem sobreviveram 2 ratos $\mathrm{e}$ mais as seguintes culturas; bacillos dyphtherico, typhico, para-typhi :o B, dysenterico FLEXNER.

\section{EXPURGOS DE PREDIOS.}

Diante dos ul imos resultados cxperimentaes obtidos, deviamo-nos convencer de que o gaz sulfuroso, pelo menos em pequenos aposentos (de 50 metros cubicos, approximadamente) en dose media de 10 grs., por metro cubico, quando applicado conveaientemente, quasi sempre consegue matar escorpiões, triatomas, percevejos, pulgas, baratas e algumas vezes o rato.

Este roedor é aliás o mais resistentc dos animaes que infestam o domicilio do homem, confirmando-se assim o scepticismo de ROSENAU com respeito aos meios de eliminação desse forte $\mathrm{e}$ intelligente inimigo.

Quanto ao nosso objectivo paresianos que, dobrada a dose de enxofre c mantidas as 24 horas para a duração dos expurgos, podiam estes ser levados á 
pratica, com algumas esperanças bem fundadas.

Valeu-nos então a Directoria de Hygiene do Estado, a qual poz á nossa disposição o material e o pessoal necessarios, confiando os serviços ao presado collega Dr. LEVY COELHO, a quem rendemos agora os nos $\cos$ cordiaes agradecimentos. Além disso, mandou vir do Departamento Nacional de Saude Publica um antigo chefe de turma para instruir o pessoal do Desinfectorio na lechnica das fumigações, a qual consistiam mais ou menos no seguinte:

A casa a expugar deve ser complelamente fechada. Em todas as frestas e em todos os orificios collocam-se tiras ou pedaços de papel impermeavel proprio para calafeto. Os objectos metalicos, dourados, etc., são protegidos por uma camada de vaselina. Abrem-se as communicacões com os forros, depois de ser todo o telhado coberto com toldos de lona, fixados por meio de sarrafos ás paredes externas do predio. Após cubação de todo o edificio, queima-se o enxofre na proporção de 20 grrs. por metro cubico, em numerosos recipienles de ferro com pés do mesmo metal, isolados convenientemente do soalho. Accesos todos os combustores, retira-se o pessoal pela unica porta livre, que então se fecha e se calafeta externamente Para iniciar e facilitar a combustão do enxofre, ajunta-se-lhe um pouco de nitro ou de alcool ou as duas substancias ao mesmo tempo.

Para maiores esclarecimentos indicamos a leitura do Tratado de Hygiene de Rosenau, que dá ao assumpto cabal desenvolvimento, embora sem referenrencias especiaes ao nosso caso.

Seguem-se alguns dos resultados obtidos em Bello Horizonte.

\section{EXPURGO No. 1.}

Casa da rua Guayacurús, em más condições hygienicas. Para contrôle fo- ram collocados em diversos pontos: 1 escorpião, 1 rato, 2 baratas e 2 percevejos. Todos morreram, após hora e meia de fumigação, bem como. grande quantidade de baratas e percerejos que ahi viviam.

\section{EXPURGO No. 2.}

Casa no Frado Mineiro. Contrôle: 1 escorpião, 1 rato, 2 barbeiros, 3 baratas e 6 ovos de percevejos. Hora e meia depois os bichos ainda se conservavam vivos; o enxofre não ardeu totalmente, talvez por causa da sua má qualidade, pois deixou como residuos verdadeiros blocos, como se fossem de pedra.

Repetido o trabalho, ainda com a mesma qualidade de enxofre, continuou negalivo o resultado. Foi preciso recomeçar o trabalho com enxofre de outra procedencia para que morressem os alludidos animaes. A casa tinha $166 \mathrm{~m}^{3}$, gastando-se no expurgo 3320 grs. de enxofre, 250 grs. de alcool c 120 grs. de nitro $\left(20\right.$ grs. de enxofre por $\mathrm{m}^{3}$.).

EXPURGO No. 3.

Casa á rua Gonçalves Dias, no. 464, com 2 salas, 6 quartos, 1 corredor, cozinha e porão $\left(688 \mathrm{~m}^{3}\right.$. $)$. Contrôle: 1 escorpião, 1 rato, 2 baratas e bezouro. Enxofre: 20 grs. por $\mathrm{m}^{3}$. Depois de $1 / 2$ hora estavam mortos todos os animaes.

Além disso, foram feitos outros expurgos quasi todos favoraveis, mas como se perderam as respectivas notas escriptas deixamos de mencional-os.

Por essa occasião, tendo a Dirctoria de Hygiene recebido um apparelho CLAYTON, resolvemos ensaial-o tambem, mais ou menos de accordo com a technica adoptada pelo Departamento Nacional de Saude Publica, 


\section{EXPURGÓS PELO CLAYTON.}

\section{EXPURGO 1 A.}

Casa da rua Bernardo Guimarães com $672 \mathrm{~m}^{3}$. Enxofre dispendido: 9050 grs. ( \pm 13 grs. por $\mathrm{m}^{3}$.); nitro: 300 grs.; alcool $400 \mathrm{~cm}^{3}$. Á distancia de $17,20 \mathrm{~m}$. do tubo transmissor do apparelho (intraduzido o tubo por uma janella) foram collocados 2 escorpiões, 2 percevejos, 2 baratas, 1 barbeiro, e 1 rato O CLAYTON foi carregado 2 vezes, funccionando 3 horas e 25 minutos. Findo esse tempo, foram encontrados mortos: os escorpiões, os percevejos (*) e 1 barata. Resistiram: 1 barata, 1 barbeiro e 1 rato.

No dia seguinte fez-se o expurgo do porão pelo mesmo processo, sendo a fumigação testemunhada por 1 rato, collocado a 9 metros do tubo transmissor, e 1 barata e 1 barbeiro a 13 metros do dito tubo. No fim de 2 horas estavam vivos.

\section{EXPURGO 2 A.}

Casa na Avenida Floriano no. 1875 Animaes de contrôle: 1 barata a 9 metros do tubo; 1 barbeiro a $10,30 \mathrm{~ms}$., 1 rato a $11 \mathrm{~ms}$; 1 escorpião a 14,80 ms. Mortos, todos elles, no fim de 3 horas.

\section{EXPURGO 3 A.}

Casa da rua Gonçalves Dias, 344. Apenas foi expurgado um compartimento com $157 \mathrm{~m}^{3}$., gastando-se $3140 \mathrm{grs}$. de enxofle $\left(20\right.$ grs. por $\left.\mathrm{m}^{3}\right), 150$ de nitro, $100 \mathrm{~cm}^{3}$. de alcool. Além disso, fez-se a desinfecção do soalho com solução de alcool. Contrôle: baratas, barbeiros e percevejos collocados a 4 metros do tubo transmissor, metade ao

(*) - J. Silvado, grande enthusiasta e vulgarizador do apparelho Clayton, fez experiencias com a pulga, o percevejo, a mosca, o mosquito, a formiga, o rato e os insectos bibliophagos, obtendo resultados positivos. alto, metade em baixo. Durante 2 horas funccionou o apparelho, mas a camara se conservou por espaço de $\mathbf{2 4}$ horas. Morreram todos os animaes.

\section{EXPURGO 4 A.}

Avenida Christovão Colombo no. 344. Foi expurgado apenas o porão dessa casa reconbecidamente infestada de escorpóes. Porão inhabitavel, escuro, sem nenhum revestimento, com as paredes cheias de buracos. Cubação: $+183 \mathrm{~m}^{3}$. Enxofre: 3680 grs. ( +20 grs. por $\mathrm{m}^{3}$ ) ; nitro 180 grs.; alcool: $200 \mathrm{~cm}^{3}$. Contrôle: 1 barbeiro, em vidro com papel perfurado, a $3,40 \mathrm{~ms}$. do tubo de transmissão, 1 escorpião a $4,95 \mathrm{~ms}$. do mesmo tubo. Depois de 25 horas, estavam ambos mortos, assim como uma rã, uma borboleta, uma aranha commum e uma tarantula, animaes esses que ahi se encontravam espontaneamente.

Além disso, informou-nos o morador do predio que durante o expurgo appareceu no pavimento superior (não fumigado) 1 escorpião, que apparecia ter sahido de um dos rodapés de madeira podre; e cinco dias depois ainda achou outro, tambem fóra do porão.

Para esse caso admittimos 3 hypotheses: a)-alguns cscorpiões tinham suas tocas fóra do porão; b)-foi imperfeita a calafelagem, que permiltiu a evasão dos arachnideos durante a fumigação da mencionada dependencia; c) -o expurgo foi insufficiente.

\section{EXPURGO $5 \mathrm{~A}$.}

Dormitorio de soldados, com $277 \mathrm{~m}^{3}$ Enxofre: 5540 grs. $\left(20\right.$ grs. por $\left.\mathrm{m}^{3}\right)$; nitro: 300 grs.; alcool: $50 \mathrm{~cm}^{3}$. Contrôle. 1 barbeiro, a $7,30 \mathrm{~ms}$. do tubo transmissor, e 1 escorpião a $10,60 \mathrm{~ms}$. do mesmo tubo. Após 24 horas estavam mortos bem como grande numero de moscas e percevejos. 
Somos os primeiros a reconhecer que é pequeno o numero de fumigações em predios naturalmente infestados.

Mas não foi sem certo esforço que conseguimos esse pouco que ahi está, o que servirá de base e ponto de partida para futuros trabalhos. As demais, não é com facilidade que se leva ao publico, a titulo de experiencia, um serviço novo cheio de incommodos e vexames para leigos indifferentes que são obrigados a abandonar suas casas e entregal-as, por algumas horas, a extranhos que as desorganizam e podem até damnifical-as.

Reconhecemos por isso que alguns desses serviços foram incompletos, ora por ter sido impossivel prolongar o expurgo por espaço de 24 horas, o que devia ser a regra, ora pela difficuldade em estender a fumigação a todos os compartimentos, o que seria sempre desejavel para maior segurança nos resultados. Tivemos, pois, de attender mais ás exigencias dos moradores do que ás necessidades do trabalho, que tinha de ser effectuado rapidamente entre as duas principaes refeições do dia.

Esses e oulros contratempos nos levaram a restringir o rigor das nossas observações, como, por exemplo, a dosagem do gaz injectado pelo apparelho CLAYTON, o que, si fosse possivel, devia ser feito com a perfeição estabelecida por DIOGO DE FARIA, na technica da extincção dos insectos bibliophagos.

Segundo a opinião do illustre Director do Desinfectorio de S. Paulo, são as seguintes as condições em que esse gaz é efliciente na lucta contra os inimigos dos livros: dose minima de $12 \%$, que se obtem no fim de 5 a 7 horas, com 1 kilo de enxofre por metro cubico. (*)

${ }^{*}$ )-O Clayton, além de outras, tem essa vantagem: queima o enxofre ao ar livre e portanto não tem, praticamente, limites para essa combustão, que só depende da capacidade da fornalha.
Além disso, o gaz dosado deve ser proveniente do ponto mais alto do aposento, graças a um dispositivo especia imaginado por esse auctor, que, como JAYME SILVADO, é um enthusiasta do gaz sulfuroso contra os devastadores das bibliothecas, aliás insectos muilissimo resistentes e que têm com os escorpióes outra analogia: graças aos seus esconderijos profundos escapam á acção dos gazes mais subtis e penetrantes.

Compele-nos, porêm, advertir que esses expurgos de livros foram quasi sempre realizados em camaras pequenas ou pequenas bibliothecas, ao passo que nós temos de agir não raro em predios amplos, de 600 e mais metros cubicos, com toda a rapidez possivel. E que tempo não seria preciso? Por que preço ficariam os nossos expurgos á razão de 1 kilogramma de enxofre por metro cubico e $12 \%$ de gaz sulfuroso nos pontos mais altos de uma casa assobradada?

Outra objecção que tambem queremos ser os primeiros a nos fazer. E' a que se refèe á falta d'uma verificação exacta do valor dos expurgos. Varias vezes tentámos documentar a efficiencia do nosso trabalho, pesquisando escorpiões vivos após a fumigação. Nada mais difficil do que descobrir esses arthropodes sem pelo menos estragar uma casa. Que o digam os operarios que costumam achal-os involuntariamente, ao desfazer uma parede, ao levantar um barrote, etc.

O ideal seria a technica de LEOCADIO CHAVES (*) para demonstrar a acção do gaz sulfuroso sobre as cabanas infestadas de barbeiros. Esse illustrado collega, após a fumigação de uma palhoca, que foi envolvida em duplo manto de lona e papel, desmanchou-a inteiramente, fazendo então a contagem de todos os triatomas encontrados, os quaes resistiram mais ou menos na proporção de $25 \%$.

(*)-Communicação verbal. 
Ora, sendo impossivel semelhante verificacão $\mathrm{cm}$ casas urbanas e alheias, somos obrigados a desistir d'ella, guardando, comtudo, a esperanca de que devemos obter igual percentagem. E' tambem possivel que a acção irritante do gaz sobre os escorpionideos consiga afugental-os das casas expurgadas, forcando-os a procurar novos pousos.

Aliás, é a nosso favor o depoimento da maioria dos locatarios das casas expurgadas, os quaes quasi sempre observam o desapparecimento dos escorpiões após o expurgo.

Por conseguinte, confrontando de um lado os nossos resultados experimentaes e de outro lado as lacunas aqui apontadas, além de outras que os compe'entes depararão n'este modesto ensaio, não nos parecem descabidas as seguintes conclusões referentes ao asstumpto:

a) - o gaz sulfuroso, pela sua acção toxica, pela sua diffusibilidade e pela innocuidade para quem o maneja, é actualmente o agente mais aconselhavel para o expurgo dos precios inçados de escorpiões.;

b)-sempre que for possivel, deve ser utilizado um ou mais apparelhos CLAYTON (conforme o tamanho do apparelho $\mathrm{e}$ as dimensões do predio) na proporção de $12 \%$ de gaz colhirlo no ponto mais elevado (*) do edificio, de accordo com a technica de DIOGO DE FARIA;

c)-na falta desse apparelho, devese recorrer á combustão do enxofre em recipientes de ferro, na dose minima de 20 grammas por metro cubico, comtanto que os combustores, sejam distribuidos profusamente pelos diversos compartimentos do immovel;

d) - podem tambem ser utilizados os cones sulfurosos, na mesma proporção servindo de recipientes quaesquer panel-

(")-Porque o gaz sulfuroso é mais pesado que o ar. las, bacias, latas, ete, mas sendo conveniente isolal-as do soatho;

e - sempre que fôr possivel, deve a fumigacão ser extensiva a todo o predio c turar 24 horas;

f)-quando for impossivel prolongala por esse espaco de tempo, deve ser repelida alguns dias depois;

g) -é imprescindivel a rigorosa calafetagem da casa;

h) -o cxpurgo é uma medida de urgencia, a unica providencia de effeitos rapidos para o combate aos escorpiões que infestam a morada humana;

i) - o cxpurgo tem vantagem de concorrer para a eliminação de outras pragas domesticas, taes como os percevejos, as pulgas, as aranhas, as baratas, as moscas, os mosquitos, os ratos, os insectos bibliophagos, etc.

j)-por mais efficiente que tenha sido o expurgo, elle não pode ser considerado como um meio prophylactico definitivo, porque nada impede que, terminados os seus effeitos, que são fugazes, os escorpiões e os outros parasitas vollem a infestar o mesmo predio.

\section{EXPURGO DE MOVEIS}

Conbecidas as contra-indicacões do gaz sulfuroso, que damnifica os metacs, os dourados, os tecidos finos e coloridos, etc, sobretudo si houver qualquer grau de humidade, poderá haver, em certas occasiões, necessidade de recorrer a outros toxicos para extinguir os escorpiões, que tambem se acoitam em moveis e ás vezes em moveis de luxo.

Em tal hypothese é indicado o emprego do xylol, mais ou menos na pro. porção de $350 \mathrm{~cm}^{3}$. por $\mathrm{m}^{3}$. Para isso o mais pratico é embeber de xylol diversas bolas de algodão, que se collocam em pequenas vasilhas distribuidas equitativamente por differentes pontos do movel, que deve ser rigorosamente fechado e calafetado com papel impermea- 
vel e gomma, porque os gaces despendidos são exiremamente sublis e diffusiveis, além de incommodos.

Experimentámos esse processo em gavetas e estantes, obtendo bons resullados, não só contra escorpiões como baratas, lepismas, aranhas e moscas. Ao cabo de 21 horas todos esses animaes morrem. O unico que pode ás vezes sobreviver é o barbeiro, principalmente sob a fórma de nympha. Mas esse mesmo fica quasi sempre mortalmente intoxicados, morrendo dias depois. Entretanto, para maior segurança dos resultados, é conveniente demorar o expurgo por espaço de 48 horas.

Esse processo é indubitavelmente caro e, portanto, de poucas applicacões praticas. Todavia, ha casos, em que é elle o unico meio de que podemos lançar mão para perseguir os escorpiões, que não raro são sorprehendidos em lugares imprevistos, Basta-nos dizer que já vimos uma escorpiôa coin todos os seus filhotes, escondida tranquillamente dentro de um piano.

Nesses e outros casos semelhantes é que o nosso processo pode ser applicado, porque, sem ler os inconvenientes do gaz sulfuroso, deve ser eflicaz contra a bicharia dos moveis e dos livros, taes como o cupim, o caruncho, o lepisma, a barata, a aranha, a formiga, etc.

Para clegar a resultados decisivos seria imprescindivel que se fizessem novas experiencias e observacóes; e na hypothese de serem ellas favoraveis, conviria que esses expurgos se repetissem no fim de 15 dias, não só para garantir a desinfestacão dos moveis como para obstar a que alguns ovos de insectos escapassem á acção toxica. E si os re ultados fossem, de facto, positivos para os parasitas das bibliothecas, talvez valesse a pena vulgarizar o processo, a despeito do seu custo elevado, porquanto seria mais um elemento para a lucla contra as pragas dos livros, sempre tão resistentes e tenazes.

\section{CASAS INADEQUADAS A' INFESTACÃO DE ESCORPIOES.}

Originarias dos campos, as especies dominantes na região central do Estado de Ninas Geraes, nomeadamente o Tityus serrulatus, encontram na maioria das residencias humanas, até mesmo nas cidades, as condições necessarias á vida: esconderijos profundos, olscuridade, socego e alimentação.

Preferem por isso os porões escuros, baixos, inhabitaveis, despidos de revestimento. Qualquer fresta lhes serve: um espaço existente entre dous tijolos ou duas periras, um intersticio sob os barroles, emfim, qualquer uma dessas pequenas lacunas das edificacões mal acabadas, o que, infelizmente, constitue a regra no nosso meio.

Na estacão fria, tudo vae relatimente bem: é muito raro um escorpião sahir espontaneamente do seu abrigo. Passado, porêm, o periodo de bibernação, logo ás primeiras chuvas de Setembro ou Outubro, mal anoitece, surgem elles, silenciosamente para o exercicio de todas as suas funcções. Então, de regra, deixam as suas tocas no porão, sohem pelas paredes do mesmo, atravessam um inlervallo entre duas taboas no soatho ou dão a volla atravez de um rodapé de madeira encarquilhada ou pôdre c fazem sua entrada imperceptivel nos comparlimentos habitados.

A melhor garantia contra os accidentes escorpionicos está, pois, em construir os predios de maneira tal que os tornem inhabitaveis para semelhantes hospedes. Naluralmenle, esse larefa pertence á architectura e á engenharia sanitaria, que de posse dos dados fornecidos pelos naturalistas poderão estabelecer regras para tal fim. Mas emquanto não se consegue esse desidertum, julgamos acceitaveis as seguintes normas, algumas das quaes pertencem ao Regulamento do Departamento Nacional de Saude Pu- 
blica e ao Codigo Sanitario do Estad de S. Paulo:

1a.-Toda superficie do sólo occupada pela construcção será revestida por uma camada continua isolante da humidade, e que a proteja da invasão dos ratos, constituida por um dos seguintes revestimentos:

a) - camada de concreto de cimento, de $0 \mathrm{~m}, 10$ de espessura, de traço de 1:3:6, no minimo:

b)-camada de asphalto de 2 centimetros, sobre uma calçada de pedra tomada com argamassa de cimento, com a espessura de 0m,10 no minimo;

c)-ladrilho ceramico, sobre uma camada de pedra lomada com argamassa de cimento, com espessura minima de $0 \mathrm{~m}, 10$.

$2^{a}$.-As paredes internas dos porões tambem serão revestidas de camada impermeavel e resistente (cimento, por exemplo) até $0 \mathrm{~m}, 30$ de altura, pelo menos, e d'ahi para cima cuidadosamente rebocadas e caiadas, de modo que não haja frestas, pequenas que sejam;

3a.-Não serão permittidos porões menos de $11 / 2$ metro de altura;

4a.-Não poderá ser empregada : argilla nas argamassas e nos rebocos das construcções;

$5 \mathrm{a}$. - As extremidades dos barrotes levarão uma boa camada de pixe, assim como as extremidades de todas as taboas, a parte das esquadrias que estiver em contacto com as paredes, emfim, tudo quanto, na construcção, fôr de madeira e não estiver inteiramente exposto ao ar.

6a.--Só serão permittidos os rodapés de cimento ou ladrilhos;

7a.-São contra-indicados os lambris ou guarnições e enfeites de madeira nas paredes;

8a.-Todas as taboas do soalho serão perfeitamente unidas e calafetadas;

9a.-Serão considerados anti-hygienicos os entrevãos, isto é, os espaços vasios entre forros e soalhos;

10a.-Todos os compartimentos destinados a cozinha, copa, despensa, ba- nheiro e latrina, terão as paredes revestidas, até $1 \mathrm{~m}, 50$ de ladrilhos ou azulejos, e piso revestido de ladrilho, sendo as juntas tomadas de cimento. Nas zonas ruraes e villas operarias, será permittido que esses revestimentos sejam de cimento, comtanto que não tenham fendas;

11a.-Não será permittida a habitação em casa cujas paredes internas e externas não tenham sido rebocadas, caiadas ou pintadas;

12a.- Tambem deverão ser rebocadas e caiadas as paredes internas que ficam acima dos forros;

13‥-Serão prohibidas as paredes de adobe e as de sopapo, assim como as coberturas de capim e de outros vegetaes;

14a. - Em torno de todo o predio, bem como nos pateos e areas internas, haverá, um passeio resistente e impèrmeavel de 1 metro de largura, no minimo;

15a.-Não serão permittidos os muros de taipa, nem os de pedra e tijolos que não tenham sido cuidadosamente rebocados;

16a.-Serão prohibidos os depositos de lenha no interior ou ao lado das habitações, só sendo permittidos, para esse fim, os telheiros abertos, longe das casas, mais ou menos collocados no meio do terreiro das gallinhas;

17a.-Serão contra-indicados os fornos de barro, de cupim ou mesmo de tijolo não rebocados;

18a.-Para que um predio recentemente construido ou reconstruido seja considerado habitavel será necessario que uma auctoridade competente o examine, verificando o cumprimento das exigencias referidas e suggerindo outras que forem recommendaveis em cada caso.

Essas disposições, que ahi ficam mais ou menos resumidamente, alliadas ás boas regras de construcção e de 
hygiene domicilaria frequentementè desprezadas) poderiam ser incluidas nos regulamentos ou posturas municipaes de todas as cidades e villas, pelo menos as situadas nas zonas infestadas de escorpiões, devastadas pela doença de Carlos Chagas, sujeitas a epidemias de peste, etc.

Fazemos, pois, um appello aos poderes publicos do nosso paiz, não só aos Presidentes e Governadores de Estados, como principalmente ás Camaras Municipaes, para que estudem e critiquem as idéas aqui apresentadas, submetendo as ao juizo dos competentes, isto é, dos biologos, hygienistas e engenheiros sanitarios. E si, por ventura, ellas merecerem tão honrosa sancção, que sejam para logo postas em pratica, afim de que milhões de nossos patricios não continuem a viver em promiscuidade com arachnideos venenosos, insectos transmissores de molestias incuraveis, murideos depositarios de bacillos pestiferos, já não fallando em outras pragas domesticas que a hygiene condemna e o asseio repelle.

\section{III}

\section{MEDIDAS COMPLEMENTARES.}

Além do expurgo, que é a medida de emergencia, capaz de no minimo reduzir o numero de escorpiões numa casa infestada; além das obras aconselhadas no capitulo anterior e que são a melhor das garantias contra a invasão escorpionica, ha ainda outros meios auxiliares, que devem ser tomados em consideração.

Em primeiro lugar, é claro que, mesmo no caso de se tratar de uma residencia á prova de escorpiões, ninguem terá o direito de esquecer as comesinhas regras de hygiene domiciliaria, mormente num clima tropical, como o nosso. Entre estas, merece especial recommendação a lavagem frequente de todos os pavimentos e especialmente dos porões da casa com soluções ao mesmo tempos antisepticas e parasiticidas: lysol a $4 \%$, creolina a $5 \%$, acido phenico a $5 \%$, etc. Essas soluções devem ser feitas com agua quente, a 50 oC., ao menos, pois augmentam com isso o seu valor germicida e parasiticida.

Não basta, porêm, a simples lavagem dos pavimentos. $\mathrm{E}^{\prime}$ imprescendivel tambem a vasculhadela de todo o predio, a limpeza debaixo, por traz e dentro dos moveis, a matança systematica de aranhas, baratas etc., porque esses bichos são os alimentos predilectos dos escorpionidas.

Aliás, são tão vulgares esses consethos que nos dispensamos de insistir na necessidade da sua applicação.

Não cessaremos, porêm, de recommendar o maximo cuidado para que seja evilada a reinfestação das casas. Isso poderá facilmente acontecer, si não se tomarem caulelas especiaes com a lenha, os maleriaes de construcção, emfim, com tudo que provém dos campos. A lenha, sobretudo, é o maior vehiculador de escorpiões, os quaes por esse mèio se introduzem nas nossas vivendas; e quando ahi não encontrem o cobiçado refugio, podem eventualmente froduzir maleficios.

Para impedir a entrada d'esses indesejaveis, o ideal seria construir nos terrenos de cada propriedade uma camara de desinfecção onde a lenha soffresse o expurgo pelo gaz sulfuroso antes de ser utilizada.

Mas, como essa providencia só poda ser aproveitavel em casos muito excepcionaes, inserimos entre as normas do construcção a clausula no. 16 , cuja explicação virá nas linhas que se seguem.

\section{ANIMAES ESCORPIOPHAGOS.}

VITAL BRAZIL, o grande organizador da campanha anti-ophidica no nosso paiz, acredita no auxilio efficaz da mussurana (Oxyrhopus claelia) que é uma 
scrpente inoffensiva, capaz de devorar oulros ophidios, inclusive os venenosos. F. IGLESIAS recommenda como ophiophago o cangabá (Conepatus chilensis) pequeno mammifero que vive no nosso continente e tem a propriedade dé èmittir um liquido nauseante e toxico. Finalmente, A. CALMETTE, com a sua inejavel auctoridade, esposa as idéas de V. BRAZIL e apresenta outros casos interessantes de ophiophagismo.

Assim tambem para os escorpiões seria licito esperar que houvesse animaes resistentes ao respctivo veneno $\mathrm{e}$ com capacidade para devoral-os impunemente.

Percorrendo a exigua bibliographia que nos foi dado compusar, encontrá. mos no excellente trabalho de WILLIAN WILSON uma lista de animaes immunes á peçonha dos escorpiões do Egypto. Esses animaes são 5 mammiferos: Gerbilus pyramidum, Jaculus jaçlus, Vulpes zerda, Ictonix libyca e Erinaceus auritus; e 1 reptil: Veranus cinereus. Não refere o autor nenhuma propriedade escorpiophaga, acreditando apenas que a mencionada resistencia deve ter sido adquirida no deserto, onde vivem as ditas especies $\mathrm{em}$ contacto com os escorpiões mais frequentes n'aquella zona, isto é, o Buthus quinque striatıs, o mais commum e mais nocivo de todos, o Prionunurus citrinus e o Buthus maurus.

CHARLES TODD, estudando na mesma região, verifica accentuado grai de immunidade em um rato que vive commumente nas habitações indigeras: o Acomys cahirinus. Mas não the attribue nenhuma virtude, nem tamponco ao Mus musculus e $M$. alexandrinys, que aliás são sensiveis, segundo o mesmo experimentador.

$\mathrm{Na}$ sua magnifica these inaugural, HEITOR MAURANO assim resume essa importante questão: "São os vertebrados, os molluscos e os arthropodes os mais sensiveis..." e, "segundo os trabathos de LAFFUIE, os animaes que occcupam a hierarchia mais baixa na serie zoologica parecem se: completamente indifferente á acção do veneno".

Quanto aos insensiveis, diz que "0 ga:o é resistente, tanto que gosta cxtraordinariamente de caçar escorpiões». Dános tambem uma curiosissima observavação pessoal, i!lustrada por um desenho proprio, em que o nosso rato commum se defende de um escorpião, «immobilizando-o com as patas dianteiras e extirpando com os denle; de um golpe habil certeiro, a vesicula do venéno".

Tratando-se do maior e melhor trabalho nacional sobre o assumpto, era natural que desejassemos aproveitar as observacões e experiencias d t $\mathrm{H}$. MAURANO para o fim por nós collimado.

No que respeita ao gato, só uma vez o vimos ás vollas com um escorpião, mas não nos consta que elle tenha grande predilecção por essa presa, que the não pode offerecer alimento farto e carnudo, como os ratos e os passaros quie são incontestavelmente a caça favorita desse felino. $O$ gato, portanto, não é um elemento com que se possa contar na guerra contra os escorpionideos.

Quanto ao rato, ainda que fosse um grande mulilador de escorpiões, o que de facto não é em condições naturaes, ninguem seria capaz de admiltil-o como alliado do homem, nem mesmo contra um inimigo commum.

No emtanto, mais de um antigo murador de Bello Horizonle nos havi. referido que as gallinhas communs ratam e comem os escorpiones que lhes passam ao alcance, Consultando, porêm, os auctores, deparamos em M. GUYON, uma affirmativa categorica a res. peito da receptividade do cão e do coelho, entre os mammiferos, e da gallinha e o pombo, entre as aves. Embora se trate de um arachnideo diffe cnte do nosso (Androctonus funestus) assevera-se esse autor que essas duas aves usocccombent 
fréquemment et rapidement àsa piqûre, voire même à cclledel'Androctonus occitanus».

Finalmente, H. MAURANO, apezar de haver observado "certas aves, sobretudo gallinaceos, ingerirem impunemente grande numero desses arachnideos", é o primeiro e reconhecer que «as aves tambem facilmente succumbem ao veneno do escorpião".

Deante de taes factos mais ou me. nos contradictorios, resolvemos fazer algumas experiencias, que confirmaram plenamente o alto grau de escorpiophagismo de que é dotada a gallinha, que devorou avidamente 8 escorpiões vivos (Tityus serrulatus) e parccia disposta a acceeitar maior numero, si o tivessemos para dar-lhe. Não só as adultas, mas tambem os frangos são capazes de ingerir impunemente escorpiões, conforme tivemos ensejo de observar, dando a um franguinho de 5 mezes um $T$. serrulatus. vivo. $O$ pequeno gallinaceo, não obstante estar bem alimentado, comeu-o com tal soffreguidão que teve de regorgital-o para logo após ingeril-o definitivamente.

Além dessas experiencias que já nos induziam a crer na immunidade da gallinha, que engole os arachnideos ainda vivos, com veneno a gottejar na ponta do aguilhão, pedimos ao distincto collega Dr. OCTAVIO MAGALHÃES, a quem compete o estudo da parte physiologica, pedimos-lhe a fineza de verificar a resistencia desse gallinaceo. $\mathrm{E}$ elle, effectivamente, a verificou bastante accentuada

Isto posto, não temos a minima duvida em affirmar que a gallinha é o animal escorpiophago por excellencia, e como tal pode e deve ser indicado como optimo elemento auxiliar na lucta antiescorpionica.

Como, porêm, aproveital-a?

Si fosse possivel installal-a no interior das nossas habitações, ao menos nos porões infestados, estaria resolvido a questão. Mas nenhum hygienista seria capaz de approvar semelhante conselho.

Todavia, como é sabido que na maioria dos casos os escorpiões são trazidos pela lenha, é logico que esta deverá ficar ao alcance das gallinhas, conforme prescreve a clausula $n^{\circ} .16$ das nossas normas de construcção. E essas aves, com a avidez e a pertinacia com que escabicham tudo, se incumbirão assim de defender os nossos domicilios.

Suppomos tambem que nas chacaras e pequenas propriedades agricolas onde a criação vive em liberdade ao redor das residencias, devem ser muito mais raros os escorpiões, porque as gallinhas os devoram antes que consigam penetrar no interior das casas.

Não obstante o auxilio efficaz que as gallinhas podem prestar-nos, não se devem abandonar os outros cuidados e cautelas, porque o escorpião é um animal subtil, mysterioso, noclivago, que pode facilmente enganar o homem, furtando-se aos meios de combate de que este dispõe.

\section{CONCLUSÕES.}

Em vista dos factos, experiencias e raciocinios aqui apresentados, parecemnos acceitaveis as seguintes conclusões de ordem pratica:

1a.- E' perfeitamente exequivel um plano de combate aos escorpiões, particularmente aos do genero Tityus que em certas zonas do Brazil central invadem a habitação humana e determinam accidentes que podem ser graves nas crianças;

2a.-Esse plano de combate consiste em 3 ordens de medidas, que se completam umas ás outras:

a)-expurgo dos predios infestados;

b)-construcção de casas improprias á domiciliação dos escorpiões;

c)-medidas complementares.

3a.-Nas cidades que dispoem de serviço sanitario bem organizado, como Bello Horizonte, ninguem deveria mu- 
dar-se para uma casa sem primeiro requisitar o expurgo da mesma;

4a.- Nas localidades não dotadas de repartição sanitaria, as camaras municipaes deveriam crear pelo menos uma turma de 3 a 4 homens, que, á maneira das que em alguns logares, existem para a matança das formigas, se incumbissem de executar os expurgos, de accordo com as instrucções ministradas pelas Directorias de Hygiene dos Estados;

5a.- O expurgo é uma medida de urgencia para perseguir os escorpiões e outras pragas que costumam incar os domicilios humanos;

6a.-Por mais efficiente que seja um expurgo, elle não pode ser considerado como um meio prophylactico radical, porque, terminados os seus effeitos, os escorpiões e toda a bicharia domestica voltarão a infestar o mesmo predio, si este não tiver soffrido uma reforma especial;

7a.-A melhor garantia contra a invasão escorpionica e de outros hospedes indesejaveis é a construcção dos predios de maneira tal que os tornem inadequados á vida desses animaes;

8a.-Todas as municipalidades deviam estabelecer leis e regulamentos sobre construcção e reconstrucção, afim de impedir que se edificassem vivendas humanas sem a observancia dos preceitos por nós suggeridos;

9a.-Pelo menos nos climas tropicaes, sujeitos a epidemias e endemias, como a peste, a doença de CARLOS CHAGAS, etc., taes normas de construcção deviam ser systematicamente adoptadas, porque, além do mais, seriam de reaes vantagens na prophylaxia das mencionadas molestias e na extincção de varios parasitas.;

10a.-Nos municipios ricos poderia ser aconselhada a compra de escorpióes, pelos menos os capturados no perimetro das cidades, com o fim de reduzir o numero dos mesmos e encaminhal-os para os Institutos que se incumbem de preparar o sôro anti-escopionico, unico remedio efficaz para o respectivo envenenamento;

11a.-E' muito aconselhavel a criação abundante de gallinhas nas zonas infestadas de escorpióes, porque essas aves intelligentemente aproveitadas, são capazes de auxiliar o homem na campanha anti-escorpionica;

12a.-Seria muito desejavel uma cooperação mais intima de zoologos, hygienistas, engenheiros sanitarios e architectos para o fim de elaborarem, de commum accordo, minuciosos projectos de casas destinadas ás zonas tropicaes.

Bello Horizonte, 3 de Maio de 1922. 


\section{Explicaçĭo da estampa 1.}

Figura n. 1.

Conc sulfureo em começo de combustão n'um recipiente de ferro proprio para expurgos.

Figura n. 2.

Porão de uma casa inçada de escorpiôes (Tityus serrulatus). (Photographia com luz de magnesio).
Figura n. 3.

Porão de uma casa de onde desappareceram os escorpiões depois que foi reformada de accordo com os dados por nós fornecidos (Photographia com luz de magnesio).

Figura 11. 4.

Instantaneo de uma gallinha a devorar um escorpião. 


\section{Bibliographia.}

HEITOR MAURANO

LLOYD H. MILLS.

EMILE BLANCHARD

CASTELLANI and CHALMERS-

OTTO TASCHENBERG

ROSENAU

JAYME SILVADO

DIOGO DE FARIA

EURICO VILLELA

EURICO VILLELA

MARIE PHISALIX

ADOLPHO LUTZ, e OSWALDO MELLO

ADOLPHO LUTZ, C OSWALDO MELLO

M. GUYON

WILLIAM H. WILSON

CHARLES TODD

GEORGES GUENAU D

VITAL BRAZIL
- Do escorpionidismo-These-Rio de Janeiro1915.

- Mexican scorpions and the treatment of scorpion sting-Boston Medical and Surgical. Journal, 1912, pag. 183.

- L'organisation du règne animal, Arachnides, 1852.

Manual of tropical medicine-London, 1910.

- Die gifligen Tiere-Stultgart-1909.

- Preventive Medicine and Hygiene.-1919.

- Desinfecções e desinfestações na bahia da Guanabara, 3a. ediçã̃o, 1919-Rio de Janeiro-Imprensa Nacional.

- Os inimigos dos nossos livros--1919-S. Paulo.

- Sorotherapia anti-escorpionica, 1a. communicação. Brazil Medico-1917, pag. 393.

- idem, 2a. communicação-Brazil-Medico--1918, pag. 161.

- Animaux venimeux et venins, 2 vols., Paris, 1922.

Cinco novos escorpiões brasileiros dos generos Tityus e Rhopalurus, "A Folhal Medica", 1922, pag. 25.

Contribuicão para o conhecimento dos escorpiões brasileiros- - A Folha Medica", 1922, pag. 41.

- Du danger pour l'homme, de la piqûre du grand Scorpion du Nord de l'Afrique, Androctonus funestus (Hempr. et Ehrenb.)-C. R. des S. de l'Academie des Sciences-1864, 59, 533.

- On the venom of scorpions-Records of the Egyptian Gouvernm. School of Med. vol. II.

- An anti-serum for scorpion venoms-Journal of Hygiene. 1909, pag. 69.

- Entomologie el parasitologie agricoles-Paris 1917.

- La defense contre l'ophidisme, 2me. edit. 1914-S. Paulo. 
25

THEOPHILO TORRES

VITAL BRAZIL

F. IGLESIAS

A. CALMETTE

A. CALMETTE
- Prophylaxie de la lièvre jaune au BrésilLyon. 1914.

- Contribuição ao estudo do envenenamento pela picada do escorpião e seu tratamentoColletanea de trabalhos-Instituto de Butantan-S. Paulo, 1918., pag. 67.

- Sobre um mammifero ophiophago do Brazil-Annaes Paulistas de Medicina e Cirurgia 1917, pag. 210.

- Sur quelques animaux destructeurs des serpents venimeux-Bull. de la Soc. de Path. exotique, 1921, pag. 3.

-Les venins, les animaux venimeux et la serotherapic anti-venimeuse.-Paris, 1907.

Regulamento dos serviços a cargo do Departamento Nacional de Saúde Publica"Diario Official", 4-Setembro-1921.

Codigo sanilario do Estado de S.. Paulo-1918, Typographia do Diario Official.-S. Paulo. 


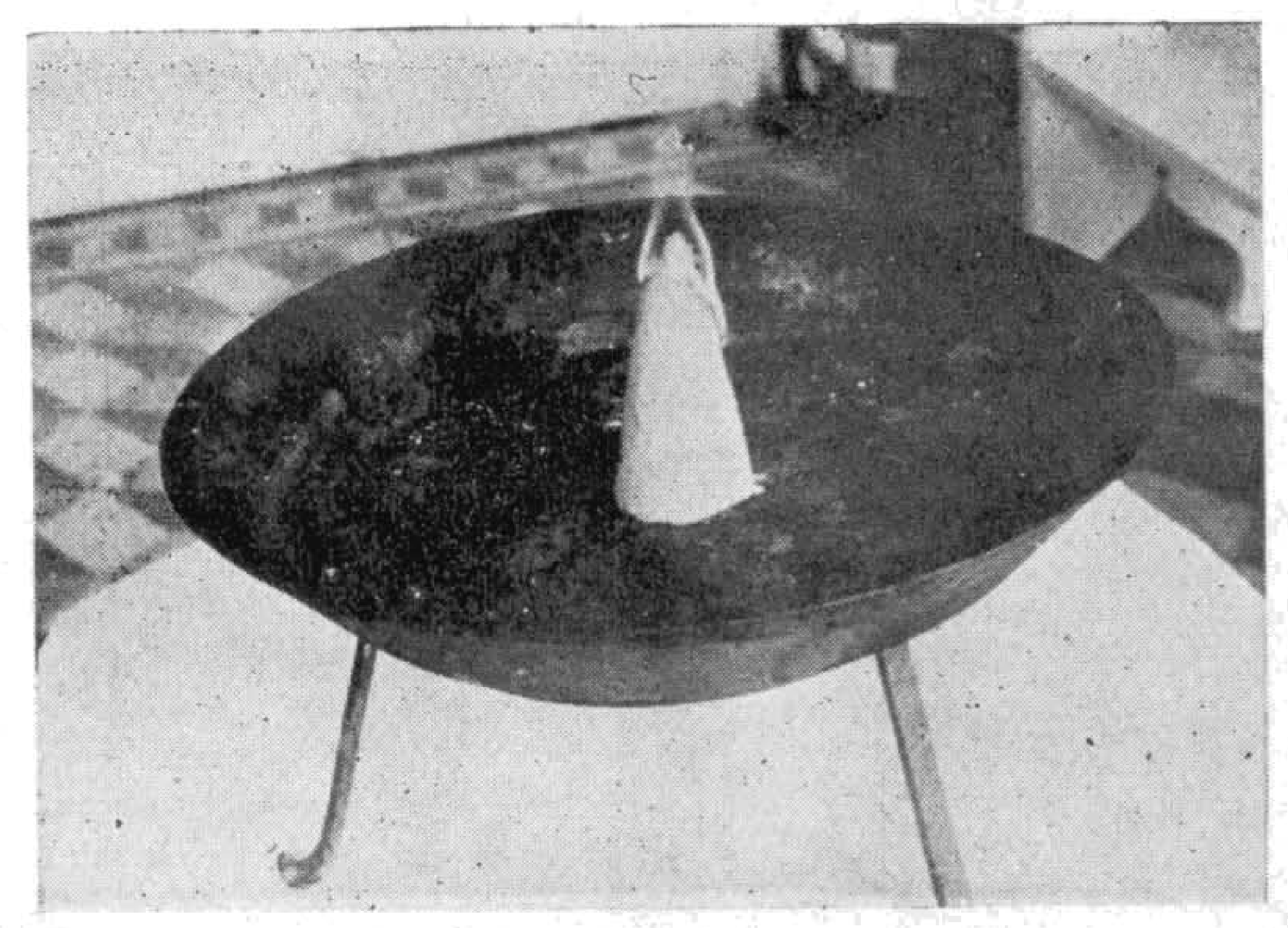

Fig. 1

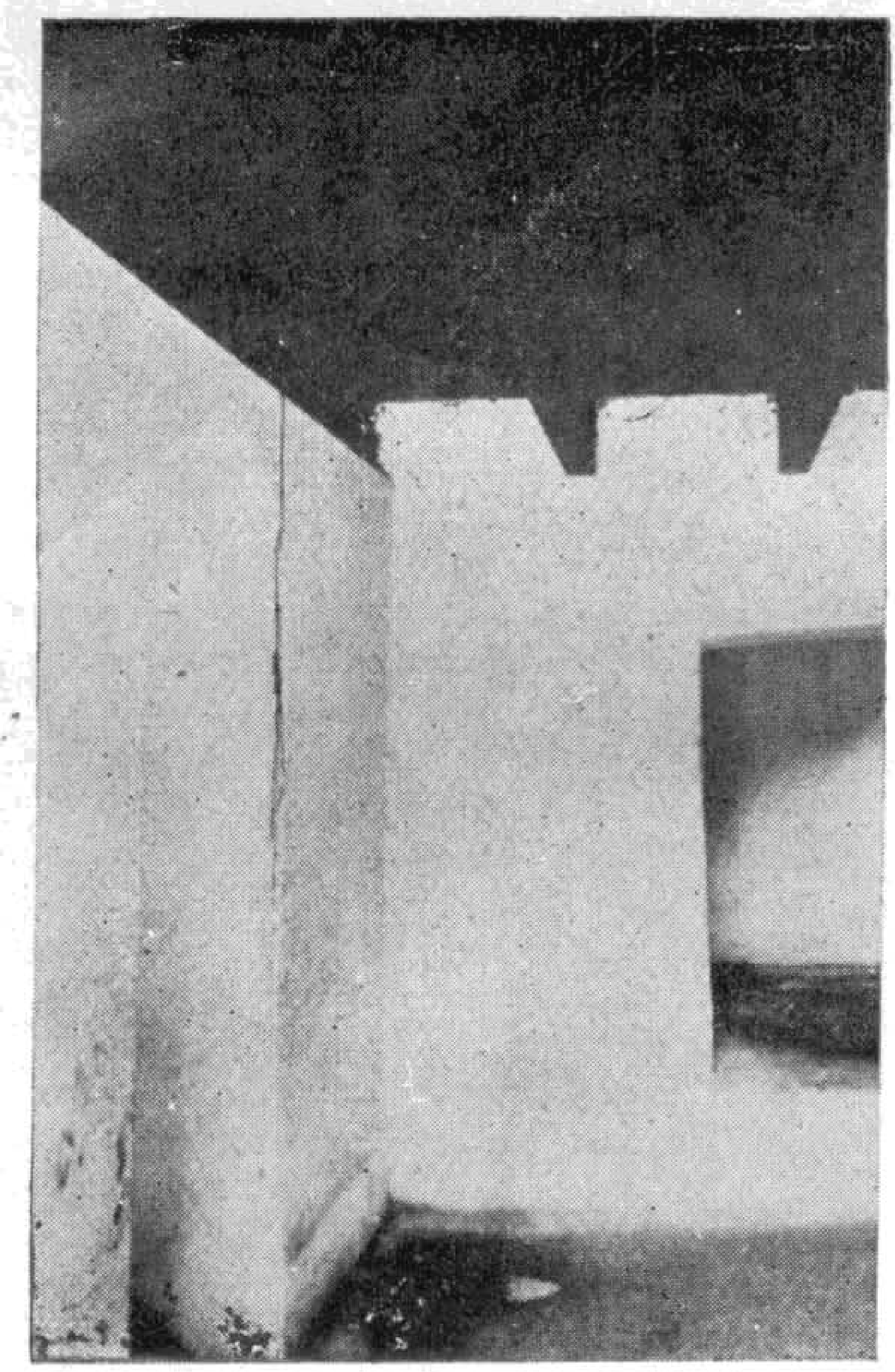

Fig. 3

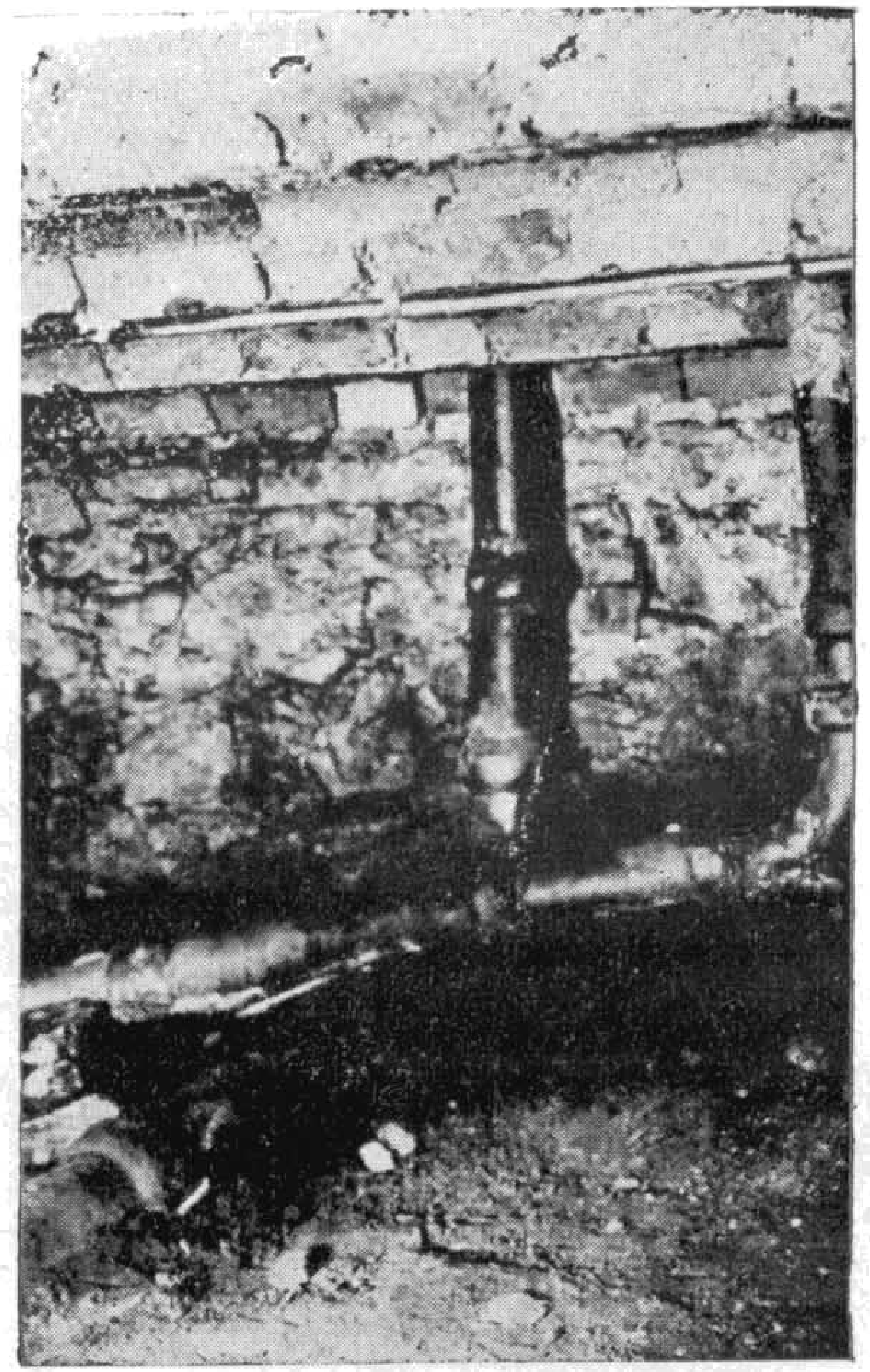

Fig. 2

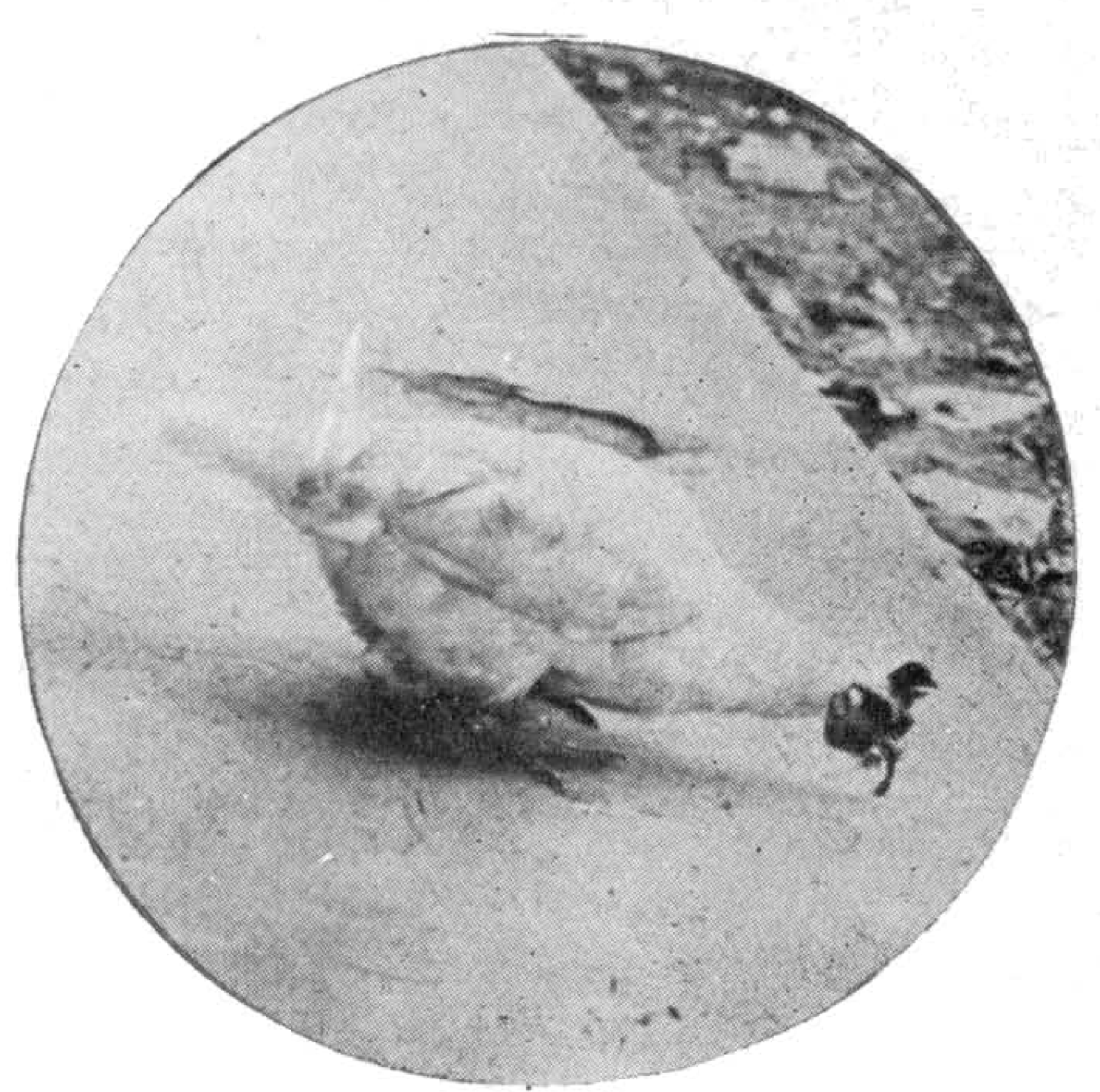

Fig. 4 